\title{
Antiproliferative Activity of Ethanolic Extract of Ciplukan Herbs (Physalis angulata L.) on 7, I 2- Dimethylbenz[A]Nthracene-Induced Rat Mammary Carcinogenesis
}

\author{
Ameilinda Monikawati, Sofa Farida, Laras Widawaty Putri, \\ Yurista Gilang Ikhtiarsyah, Edy Meiyanto* \\ Cancer Chemoprevention Research Center, Faculty of Pharmacy, \\ Universitas Gadjah Mada, Yogyakarta, Jalan Sekip Utara 55281 (Telp. 02746492662 Fax. 543120)
}

\begin{abstract}
Physalis angulata L. is an annual herb widely used as popular medicine for the treatment of cancer. Physalis angulata L. ethanolic extract (PEE) has been demonstrated to have strong cytotoxic activity against breast cancer, inhibited cancer cell's proliferation and induced cell cycle arrest. The aim of our study is to investigate the effect of PEE as a cancer chemopreventive agent on 7,12-dimethylbenz[a]nthracene (DMBA)-induced rats mammary. The antiproliferative activity was characterized by monitoring the histopatology representation and expression of cell proliferation on DMBA-induced mammary rats that were treated with PEE against control groups. The histopatology representation were analyzed by Haematoksilin Eosin (HE) staining method, while proliferative activity was detected by AgNOR method. The HE staining results showed significant differences in cells morphology of treatment groups compared to the control groups. Thus results suggest that PEE was able to repair morphology of cells undergoing carcinogenesis. AgNOR method showed decreasing occurrence of black dots between treatment and control groups. Thus, we conclude that PEE has an antiproliferative activity on DMBA-induced rat mammary. Therefore, the ethanolic extract of Physalis angulata herbs is a potential chemopreventive agent on cancer. Further study on its molecular mechanism needs to be explored.
\end{abstract}

Keywords: Physalis angulata, breast cancer, 7,I2-dimethylbenz[a]nthracene, carcinogenesis, antiproliferative

\section{INTRODUCTION}

Breast cancer is one type of cancer that have a high prevalence and the second most common cancer worldwide after cervical cancer cause mortality (Parkin et al., 2008). Cell proliferation plays an important role in multistage carcinogenesis with multiple genetic changes in cancer. Therefore, control of cell proliferation is important for cancer prevention.

Diet is considered as one of the major factors accounting for the variability in cancer incidence and mortality. Plant phytochemicals are receiving considerable attention for their potential role in reducing cancer risk. Some researchers reported that compounds in plants can be potentially as an anticancer agent (Cardenas et al., 1998).
Ciplukan (Physalis angulata L.) has been reported as a potential cancer chemo-preventive agent. Anticancer activity shown by fisalin isolated from Physalis angulata. In a previous study reported that the antitumor activity of Physalis angulata related to the inhibition of cells proliferation and had also been shown to possess antiproliferative, cell cycle arresting properties in vitro on several cancer cell lines (Hemerson et al., 2006). Hsieh et al. (2006) mentioned ciplukan role in the regulation of proliferation, the inhibition phase of the cell cycle through G2/M and on apoptosis of human breast cancer cells MDA-MB231.

*Corresponding author e-mail : meiyan_e@ugm.ac.id 
This study is aimed to observe in vivo antiproliferative activity of PEE on DMBAinduced rats mammary carcinogenesis in Sprague Dawley rats with respect to histopatology representation of mammary tissue and inhibition of cell proliferation using AgNOR staining method. Recently it has been reported that the quantity and distribution of AgNOR index reflect good prognosis and degree of malignancy and proliferation of carcinoma cells, such as breast cancer (Chen et al., 2003).

\section{MATERIALS AND METHODS}

\section{Plant Material and Extract Preparation}

Physalis angulata herbs were collected from Sleman, Yogyakarta, and the determinations was carried out at the Laboratorium Farmakognosi Bagian Biologi Fakultas Farmasi Universitas Gadjah Mada. Fresh herbs were rinsed, dried, and powdered. Extraction was done by maceration with $96 \% \%$ ethanol $(1: 10)$. Filtrate was then concentrated using Rotary Evaporator to obtain concentrated extracts.

\section{Animals}

Female Sprague Dawley Rats, aged 30 days, weighed from 86 to $112 \mathrm{~g}$ were purchased from Unit Pengembangan Hewan Percobaan Universitas Gadjah Mada. Test animals were raised in ambient temperature $\left(25-30^{\circ} \mathrm{C}\right)$, fed with pellet and tap water.

\section{Chemicals}

96\% ethanol (Merck, Darmstadt), aquadest (Asia $\quad$ Lab), $\quad 0.5 \% \quad$ CMC-Na, 7,12dimethylbenz $[a]$ anthracene (Sigma Chem. $\mathrm{CO}$, St. Louis, MO), corn oil, $0.9 \% \mathrm{NaCl}$, formalin buffer (Asia Lab), Phosphate Buffer Saline (PBS) (Sigma), hematoxylin and eosin, 33\% silver nitrat solution, sodium citrate buffer, xylen.

\section{Treatment}

There were 5 groups, containing 5 rats in each group. DMBA were dissolved in corn oil respectively. DMBA with the dosage of 20 $\mathrm{mg} / \mathrm{kgBW}$ were given orally in the first 5 weeks, twice a week, while PEE were given everyday for 2 weeks, during the $9^{\text {th }}$ and $10^{\text {th }}$ week. PEE were suspended in $0,5 \% \mathrm{CMC} \mathrm{Na}$.

The first group acts DMBA control group, being treated with DMBA. The second and third group (treatment group) were given $\mathrm{DMBA}+\mathrm{PEE}$ (750 and $1500 \mathrm{mg} / \mathrm{kgBW}$ ). The fourth group was treated with CMC-Na (solvent extract control), and the fifth group was treated with PEE 750 $\mathrm{mg} / \mathrm{kgBW}$ (PEE control). Rats were then sacrificed and mammary sampling was done in the $10^{\text {th }}$ week.

\section{HE staining}

The histopatology representation of tested animals is observed microscopically with $\mathrm{HE}$ staining method. Preparat of mammary tissue were colored with Hematoxylin and Eosin dyes. Observation is done using light microscope.

\section{Cell proliferation assay with Argyrophillic Nucleolar Organizer Regions (AgNOR)}

Sections of $3 \mathrm{~mm}$ were obtained from each paraffin block of the organs. The sections were immersed in sodium citrate buffer ( $\mathrm{pH}$ 6.0), boiled at $120^{\circ} \mathrm{C}$ for 20 minutes in an autoclave then cooled to room temperature, and washed with ultrapure water. A solution of $0.66 \%$ gelatin solution dissolved in ultrapure water was prepared, to which formic acid was then added to make a final $0.33 \%$ solution. The solution and the glassware were pre-warmed to $37^{\circ} \mathrm{C}$. Then silvernitrate was dissolved in the gelatin-formic acid solution to make a final $33 \%$ solution, continued by immediately immersing the solution in the obtained solution. Staining took place with the absence of light at $37^{\circ} \mathrm{C}$ for 13 minutes. The solution was then poured off and the slides were washed with ultrapure water. The slides were covered on the object glass, then assessment was carried out under light microscope (Zeiss, German).

\section{Statistical analysis}

The antiproliferative assay was carried out by using mAgNOR parameter, it consists of the direct count by microscope of all each silverstained dot per cell, by carefully focusing through the section thickness at very high (100×) magnification from 100 cells per slides. mAgNOR refers to the mean of blackdots in the minimum 100 cells. (Derenzini et al., 2000). Data analysis used statistical one way ANOVA method continued by Tuckey test. The difference was considered significant when $\mathrm{p}<0.05$.

\section{RESULTS AND DISCUSSION}

\section{Hispatological Observation}

Microscopically, tumor development was observed in breast tissues that showed significant differences in cells morfology of treatment groups compared to the control groups. Significantcy 
occurred in the multiplicity rats mammary both in $\quad$ the mucosal and submucosal layers (Fig. 1).

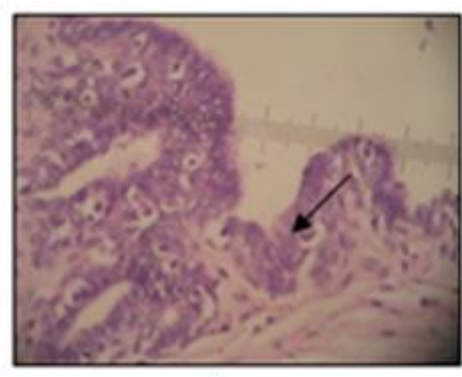

A

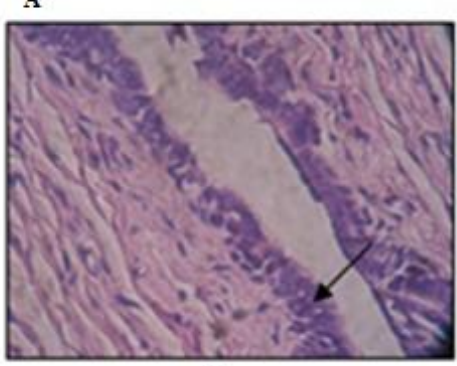

D

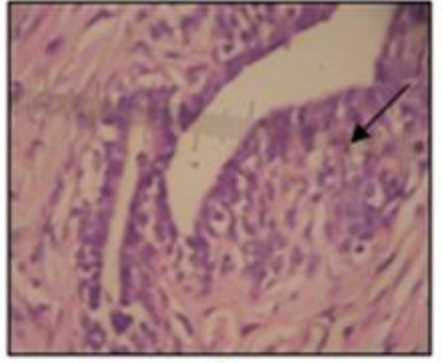

B

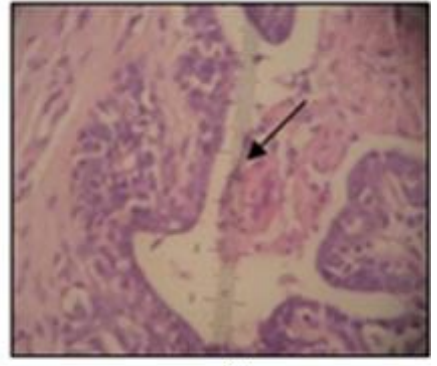

C

Figure I. HE stained histopathological representation of DMBA-induced carcinogenesis in rats mammary. (a) Control DMBA, (b) DMBA+PEE 750 mg/kgBW, (c) DMBA+PEE $1500 \mathrm{mg} / \mathrm{kgBW}$, (d) Solvent extract control, and (e) PEE control group. Nucleus cells all groups seemed normokromatis (black arrows) with haematoxylin and eosin. Control DMBA group showed that the ductus change into multilayer cells indicate occurancy of carcinogenesis. PEE-treated rat mammary showed normal mucosal folds and no infiltration of inflammatory cells. Gland epithelial cells of rat mammary control groups proliferated normally (single layer).

It was found that the incidence of invasive adenocarcinoma was significantly lower in groups treated with PEE. The inhibitory effect of PEE on breast carcinogenesis induced by DMBA in rats is evidenced by the decreased incidence and multiplicity of rats mammary. Thus results mean that PEE was able to repair morphology of cells undergone carcinogenesis.

\section{Analysis of Cell proliferation using AgNOR Staining Method}

Nucleolar organizer regions (NOR) are loops of DNA that contain ribosomal RNA genes that can be demonstrated in the interphase nucleus in histological sections by silver-staining. Moreover, the products can be visualized as black dots, which are referred to AgNORs which can be quantified. It has been suggested that the number of AgNOR dots in a nucleus may reflect the status of cell activation and therefore is a useful index to assess cell proliferation (Tanaka et al., 1993). Cancer cells have a greater quantity of AgNORs than the normal cells (Derenzini et al., 2000).

The effect of PEE in reducing cell proliferation was pronounced in treatment groups compare to control groups (Fig. 2). The epithelial mammary of DMBA group has the most black dots mean value (mAgNOR) (Fig. 3). Cell construction became closer to others and multilayer. This indicates DMBA has induced cell hiperproliferation which leads to cancer initiation. Non-treatment group showed normal cell proliferation level, confirmed by normal blackdots value (Fig. 2d, e). The extracts groups have less blackdots than DMBA group (Fig. 2b, c). It means PEE has the ability to lower epithelial mammary cell proliferation of the rats induced by DMBA. 


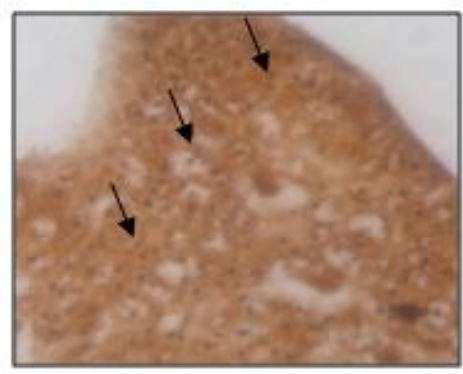

a

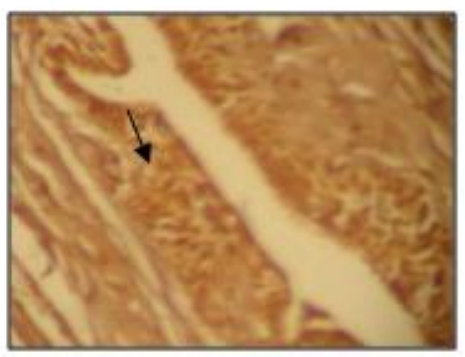

d

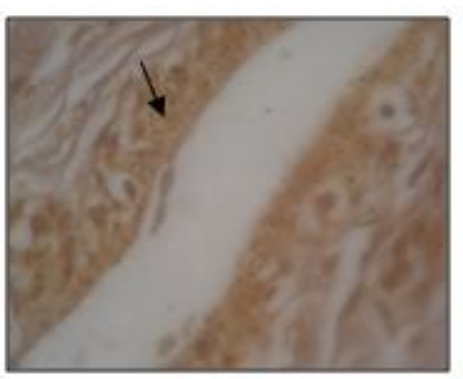

b

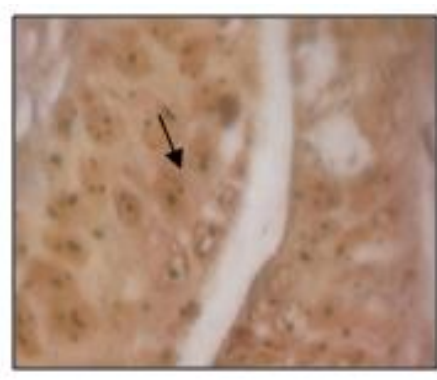

c

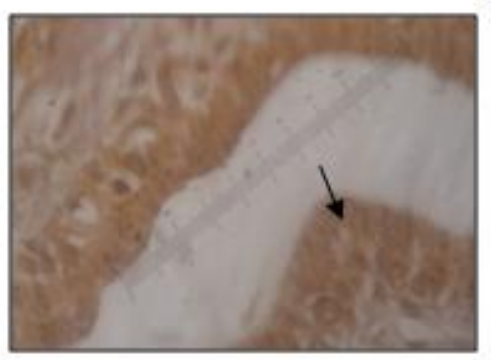

e

Figure 2. PEE inhibits proliferation of rat's ephitelial mammary. Proliferative assay was carried out by AgNOR staining. Black silver-stained dots for AgNORs were clearly identified in all cell nuclei (showed by black arrows). DMBA control group (a) have highest occurrence of black dots compare to treatments groups. Group treated with PEE $(b, c)$ have black dots less than DMBA control group which means PEE has ability to decrease cells proliferation in rats mammary induced carcinogenesis.

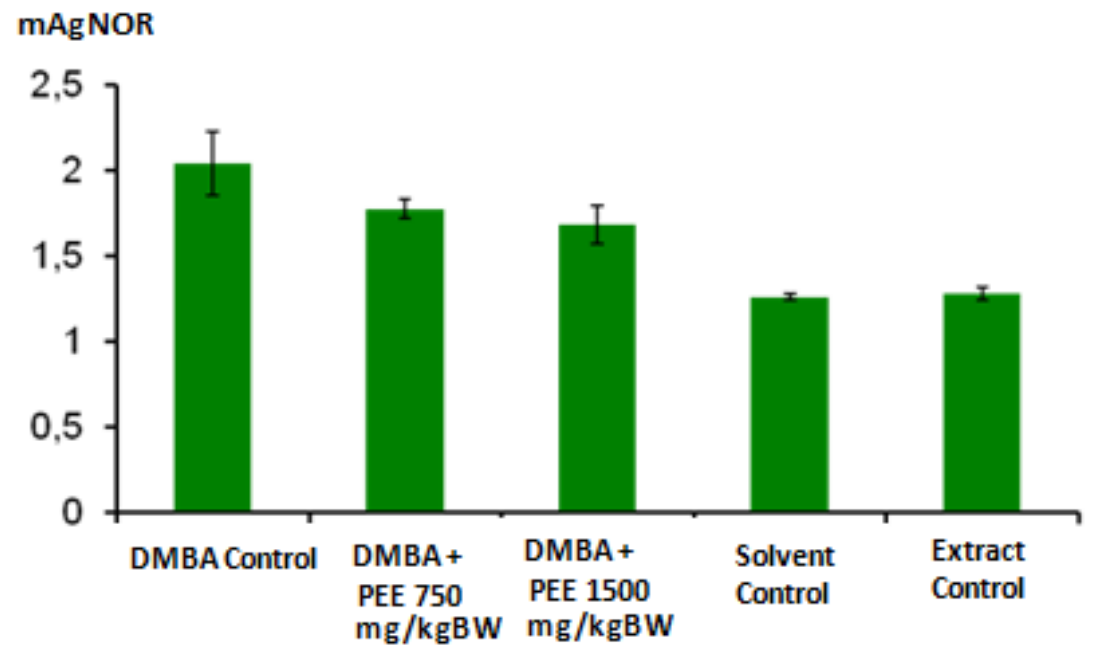

Figure 3. mAgNOR value in each treatment groups showed the level of proliferation that occurred with $3 x$ replications, deviation standard (SD) 0,36 at $95 \%$ confidence level. PEE $1500 \mathrm{mg} / \mathrm{kgBW}$ showed effective antiproliferation effect, proved by significant blackdots reduction. 
DMBA treatment group have the highest mAgNOR value which means the highest cell proliferation activity than the other groups. mAgNOR Score $(X \pm S D)$ for control DMBA, PEE $750 \mathrm{mg} / \mathrm{KgBW}$, PEE $1500 \mathrm{mg} / \mathrm{KgBW}$, PEE control and solvent extract control group are 2.04 $\pm 0.19,1.77 \pm 0.05,1.68 \pm 0.11,1.26 \pm 0.02$, and $1.28 \pm 0.04$. The mAgNOR of PEE 1500 $\mathrm{mg} / \mathrm{KgBW}$ is lower than PEE $750 \mathrm{mg} / \mathrm{KgBW}$ and not significally different with control group (ANOVA at $95 \%$ confidence level) thus means that PEE $1500 \mathrm{mg} / \mathrm{KgBW}$ able to decrease proliferation of mammary cells undergone carcinogenesis.

PEE had the ability to inhibit proliferation of epithelial mammary of DMBA induced female Sprague Dawley rats. Dosage increase corresponds to an increase in the antiproliferative effect of both cells. It has been hypothesized that the antiproliferative effects of ciplukan could be due to their ability to affect certain stages of the cell cycle in the cancerous cells. Role in regulatory processes of proliferation of PEE probably by cell cycle arrest in G2/M phase that eventually leading to apoptosis, but the specific mechanisms of these compounds on these kinase receptors and other transcription factors are yet to be determined.

The role of PEE induced G2/M arrest could be through inhibition of synthesis mRNA and their downstream protein levels of cyclin A and cyclin $\mathrm{B} 1$, increasing p21, and P27 levels, and increasing Chk2 (Hsieh et al., 2006). However, the PEE ability to increase the expression of p21, p27, and Chk2 is not yet confirmed, further study is needed to determine the claim. PEE can also inhibited cells proliferation by apoptotic mechanism through regulation of p53, Bcl-2, Bcl-xl, XIAP and other pro apoptotic protein such as Bax dan Bad (Wu et al., 2004). Therefore the expression of some regulator protein involved in apoptosis needs to be explored.

In this study, the antiproliferatif activity of PEE shown by its ability to decreased incidence and multiplicity of rats mammary histopatology and decreasing occurrency of black dots and mAgNOR on mammary carcinogenesis induced by DMBA. Nevertheless, further research to determine whether a larger dosage or longer treatment period than the experiment could increase the antiproliferative activity or not can be conducted.

\section{CONCLUSION}

Based on this results, we conclude that PEE is able to reduce cell proliferation on DMBAinduced rat mammary. Thus, PEE has the potential to be develope as anticancer agents that have mechanism of action through the inhibition of cell proliferation. Therefore, further study on its molecular mechanism and the target of action on inhibiting the cells proliferation, such as cell cycle needs to be explored.

\section{ACKNOWLEDGEMENT}

This work was supported by grant from DP2M Dikti 2010.

\section{REFERENCES}

Cardenas, L.I., Mace, D., Richardson, R.A., Wilson, .F., Shan, S. and Dewhirst, M.W., 2008, The Pervasive Presence of Fluctuating Oxygenation in Tumors, Cancer Res., 68, 5812.

Chen, M., Lee, J.G., Lo, S. and Shen, J., 2003, Argyrophilic nuclear Organizer regions in nasopharyngeal carcinoma and paraneoplastic epithelial head and neck, 25(5), 395-399.

Hemerson, I., Maria, L., Marcia, R., Paula, A., Deusdenia, O., Edilberto, R., Veras, L., Manoel, O. and Claudia, P., 2006, In-vitro and In-vivo Antitumour Activity of Physalins $B$ and $D$ from Physalis angulata $L$, Pharmaceutical Press, Journal of pharmacy and pharmacology, 58, 235-24I.

Hsieh, W.T., Huang, K.Y., Lin, H.Y. and Chung, J.G., 2006, Physalis angulata Induced G2/M Phase Arrest in Human Breast Cancer Cells, Food Chem. Toxicol., 44, 974-983.

Murray, P.G., Boldy, D.A., Crocker, J. and Ayres, J.G., 1989, Sequential demonstration of antigens and $\mathrm{AgNORs}$ in frozen and paraffin sections, J. Pathol., I 59, 553-557.

Parkin D.M., Bray, F., Ferlay, J. and Pisani, P., 2008, Global Cancer Statistics, CA Cancer J Clin, 55, 74- 108.

Rizali, E. and Auerkari, E.I., 2003, Teknik Pewarnaan Silver (AgNOR) sebagai Salah Satu Cara Menentukan Aktivitas Proliferasi Sel Tumor dan Apoptosis, Jurnal Kedokteran Gigi Indonesia, I 0(3), 4I-45.

Tanaka, T., Kojima, M., Suzui, M. and Mori, H., 1993, Chemoprevention of colon carcinogenesis by the natural product of a 
simple phenolic compound protocatechuic acid: suppressing effects on tumor development and biomarkers expression of colon tumorigenesis, Cancer Res., 53, 39083913.

Wu, S., Ng, L., Lin, D., Huang, S., Wang, S. and Lin, C., 2004, Physalis Peruviana Extract Induces
Apoptosis in Human Hep G2 Cells through CD95/CD95L System and the Mitochondrial Signaling Transduction Pathway, Cancer Letters, 21 5, 199-208. 